\title{
The Chinese Flora, its Important Position and Crisis
}

\author{
HONG DEYUAN FU LIGUO \\ Institute of Botany. Chinese Academy of Sciences, Beijing 100093 \\ (Received June 9, 1993: Revised June 18. 1993)
}

\section{The important position of the Chinese flora}

The climate in China is very diverse, varying from the tropics to cool-temperate. Such a diverse climate is unique in the world. China has three terraces from the eastern coast to Qing-Zang Plateau with the highest altitude $8848 \mathrm{~m}$, so-called "the roof of world", in the west. Such a diverse topography can not be found elsewhere in the world. The diverse climate and complicated topography have created conditions for the development of a diverse flora in China. "Iconographia Cormophytorum Sinicorum" contains 13000 species of common and economically or scientifically valuable plants in China. Most volumes of "Flora Reipublicae Popularis Sinica" (containing 125 books in 80 volumes in total) have been completed, and thus we are able to estimate that there are 28000 species of vascular plants in China. This figure is second to that in Brazil and may be roughly equal to those in Peru and Indonesia. In the Northern Hemisphere, however, it is certainly second to none.

The Chinese flora is not only extremely diverse, but also of an important position. As well known. China is one of the four major origin centers of cultivated plants, and, therefore, China possesses a large number of close relatives of cultivated plants, e. g. wild sojabean, wild rice, wild barley, wild tea, etc. . In one word, China is very rich in plant germplasm. In Xishuangbana, Yunnan Province, for example, more than 100 plant species closely related to cultivated ones can be found. These should be considered to be a treasure of China. It was reported that some American scientists took from China a decade ago a form of wild sojabean with dense white villose hairs, and a new cultivar was raised by hybridizing it with cultivated sojabean. The new cultivar is more tolerant of drought, saving $15 \%$ of water comparing with the ordinary cultivars, and thus can be cultivated in relatively poor and dry fields. This has made the United State expand its cultivation of sojabean and replace China as the largest sojabean exporter.

China has more than 7000 species of medicinal plants, which make up a great and rich treasure-house. Cancer, aids and cardio vascular deseases have recently become the most dangerous enemies of human health. Many countries, the United States, Japan and European countries in particular, very much emphasize screening medicines against such deseases from wild plants. A number of instiutions in the Chinese Academy of Sciences, are making joint efforts with some companies from the United States and Japan to screen effective compounds.

As announced in 1989, a hospital in San Francisco discovered that a Chinese traditional medicine, the root of Chinese trichosanthes could kill aids viruses and infected phagocytes, but prevent normal cells from infection, and the hospital was preparing for clinic experi- 


\section{直接copy本文内容时会有误差，请注意核对!}

ments. The originl plant of the root of Chinese trichosanthes is Trichosanthes kiriluneii. This genus consists of ca. 50 species. 40 of which. i. e. $80 \%$ of the total, are found in (hina. Therefore, it is a prospective project to study, rationally exploit and conserve plants of this genus.

China is also a kingdom of flowers. Many famous and precious flowers. e. g. rhododen drons, camellies, peonies primulas, lilies are native to (hina. In southwestern China, whenever one is in camellias forests at lower altitudes, in rhododendrons bushes at moderate altitudes or in alpine meadows seeing Primula. I'edicularis, Mecomopsis. etc. at higher alti tudes, he will feel standing in a sea of flowers. In China there are nearly 500 species of Rhododendron. more than 300 species of Primulu and over 100 species of Camellia. It is not suprising when Wilson. an English collector. said. after he made expedition to western China, that the Chinese flower is the mother of gardens in the world. European people often say that there would be no gardens without the Chinese flower.

Chinese plants are also of special value for scientific researches. The climate in the Tertiary was relatively uniform all over the earth. and thus many plants were then widely distributed in the Northern Henisphere. During the Quaternary glaciation. however, eastern Asia. Europe and North America experienced entirely different situations. In North Ameri ca, the route for plants retreating southwards was cut by the Gulf of Mexico and Maxico desert, when glacier progressed southwards, and thus they became extinct during the glaciation. The situation in Europe was even worse for plants since the Alps stood transversely in the south of Europe. When the glacier moved southwards it was impossible for plants to retreat southwards because the Alps was also covered with glacier, and therefore only a small amount of plants survived in refuges. Most of modern European plants are immigrnats from Asia and Balkan and the European flora is rather poor. In eastern Asia, there were no barriers like those in North America and Europe to prevent plants from moving southwards when the glacier progressed on one side, and the glaciation was much weaker in eastern Asia. where there is no reliable evidence of glaciation except the Taibai Mountain in Shanxi Province with the highest peak reaching $3767 \mathrm{~m}$ above sea level, on the other. Therefore. much fewer plants became extinct during the glacial period in eastern Asia and a large number of the Tertiary or even pretertiary plants still exist there. As well known. many "living fossils" are found in China. For example, Ginkgo biloba. a "living fossil", has lived for more than one hundred million years. and was once widely distributed in the Northern Hemisphere. All cultivated ginkgos in the world are introduced form China. It was reported that wild ginkgo forests still exist in the Tianmu Mountains of Zhejiang Province and a mountain of central Hubei Province, although this has not been confirmed. Metasequoia glyptostroboides was also widely distributed in the Northern Hemisphere in the Tertiary from fossil records, and was once considered extinct. Professors Hu and Cheng reported in 1947 that living plants was found in Muodaoxi Village. Lichuan County, Hubei. This report caused a sensation in the botanical world. Nearly all botanical gardens were anxious to introduce this "living fossils" soon after the discovery, which can now be found in botanical gardens all over the world. Another famous "living fossil", Cathaya argyrophylla, was described and published in 1958 by Professors Chun and Kuang and, no specimens have been available abroad so far. This plant is now only scattered in a few localities in Sichuan. Guizhou, Hunan and Guangxi.

There exist in China a large number and a great variety of "living fossils". More than 


\section{直接copy本文内容时会有误差, 请注意核对!}

200 genera and over ten thousands of species are endemic to China. There are numerous relicts among them, which are of great value for studies on systematics, evolution, plant floristics and paleogeography.

\section{Severe crisis for the Chinese flora}

As stated above, the Chinese plants are of great importance and unique position, but their existence is facing a severe crisis. Due to the explosion of human population, rapid development of industry and other causes, deforestation in China in the last four decades has been unexpectedly quick. About 25. $7 \%$ of the land in Hainan was covered by tropical forests in the early 1950's, but this figure has now been reduced to only $7.2 \%$. That is to say. $70 \%$ of forests has disappeared, decreasing by $2.7 \%$ per year. In Xishuangbana, $55 \%$ of the land was covered by virgin forests in the early 1950's, but unfortunately half of them has been destroyed. The situation in othe regions is not much better than these two. Mountainous areas in southern China, particularly in southwest China were seen green with clean and blue waters everywhere; Yunnan, Guizhou, western Sichuan, western Guangxi, and western Hunan and Hubei had large virgin forests or well-developed natural forests in the past. However, local timber loggers have now deforested towards the summits of mountains and many others have become bare in addition to slash-and-burn agriculture and firewood harvest. Outside of about 700 nature reserves which cover nearly $6 \%$ of the total land of China, one can now hardly see virgin or relatively well-developed natural forests. For the last several decades the rate of deforestation in China has been much higher than $1 \%$, the world's average rate of deforestation. The last three decades have witnessed a rapid change of the Yangtze River from green to yellow and its becoming "the second Yellow River" following the severe deforestation in the upper and middle reaches of the river. Two disastrous floods took place in the upper and middle reaches only in the 1980's, which indicates the severity of deforestation in this region.

Deforestation causes entire change of enviroments and destroys original ecosystems, and the associated plants will soon or late disappear subsequently. According to the principles of island biology, if $90 \%$ of the original environments is destroyed, one half of the total number of species there will become extinct. The other half may live in isolated and restricted habitats, which causes inbreeding and genetic drift. These factors make in turn populations weaker in competition and more vulnerable. Therefore, it is rather clear that samll nature reserves are not a reliable guarantee of conserving plants.

In addition to deforestation, reckless digging and collecting and non-controlled export of wild flowers and medicinal plants have also caused severe destruction of plant resources.

As stated above, China is a kingdom of flowers. With the improvement of human life, the flower market has been developing very rapidly. Many foreigners envy the rich flower resources of China. We are neither against the export of tissue-cultured flowers nor against the export of wild flowers on the basis of conserving plant resources. However, the present problem is, as we know, some foreign merchants come to cities in southwestern China to purchase various wild flowers, particularly wild orchids, and local people indiscriminatively dig orchids and transport by trucks to certain sites, where foreigners choose a few individuals that they want and cast all others like garbage. Some units of foreign trade and local special products only care of foreign currency but disregard conserving plant resources. They 


\section{直接copy本文内容时会有误差，请注意核对!}

export a large number of wild flowers. which causes severe exhaustion of plant resources. In 1988. China Science and Technology Commission asked our laboratory to check a list of wild flowers sent for obtaining export permission by the Yunnan Branch of Foreign Trade. Several tens of species of wild flowers were on the list, each with hundreds or several thousands of individuals having already been collected from the wild. Among them were species of I'a phiopedium which is in the Appendix I of International Trade Convention of Endangered Species, and thousands of individuals of endangered plants like I'aremia delavuyi. which are included in "China Red Data Book of plants" (Vol. 1). One can not help becoming surprised and worried about biodiversity in China when he reads such a list.

Chinese traditional medicinal herbs takes a high propportion on the pharnaceutical market and are being more and more emphasized. so that the supply is smaller than the demand. The national departments concerned purchase wild medicinal herbs in a noncontrolled way, which has caused severe destruction of wild resources of medicinal plants. For example, Paeonia papaveracea both a famous and precious flower and a source of the root bark of the peony, was rather common in the Qingling Range. However. when we made a survey on this species there in 1985. we found only three individuals, two mature and one young. on a cliff in a whole day searching for it in the mountain guided by a peasant with experience in collecting medicinal plants. But he told us that during the 1950's he could see its individuals up to one hundred and collect $50 \mathrm{~kg}$ of fresh root bark one day. It is clear that this species has become endangered only within 30 years. Neopicrorhiza scrophuluriiflora is of an effect similar in medicine to Coptis chinensis. It has been dug in a large amount without researches on its cultivation since the exhaustion of Coptis chinensis, and the former. which was rather common in the Henduan Mountains not long ago. has now become rare. An even more prominent example is wild Panax ginseng. It was not only common in Northeast China and one of the three treasures there, but also present in Shangdan district of Shanxi Province and the Wuling Mountain of Hebei Province, and the Shangdan ginseng was once famous in whole China. Not only have wild plants of the species disappeared in Shanxi and Hebei. but also they can hardly be found in Northeast 'China. The first author of this paper once spent one and half a month in the Changbei Mountains, the most aggregated area of wild ginseng, in an expedition. and visited various communities there in the mountains. However, no single wild ginseng was found. Although cultivation is successful, the temptation of high price (thousands of yuans per $\mathrm{kg}$ ) of wild one still make some people eat in the wind and sleep in the dew for illegally digging wild ginseng. It can be expected that if purchase of wild ginseng is not stopped and illegal digging is not severely punished, one can only see specimens of wild ginsengs in a herbarium in the near future.

\section{The state of endangered plants in China}

It is estimated that $10 \%$ of plant species in the world are endangered. As stated above. however, the recent declining of environments is more severe in China than in most places of the world. And reckless exploiting of plant resources is also extremely severe in China. It is rather certain that the proportion of endangered plants is higher than $10 \%$, and is estimated to be $15-20 \%$ in China. According to this estimation, $4000 \sim 5000$ species of vascular plants in China are being endangered. When we prepared a list of endangered plants of China, we asked for the information from all relevant institutions in China. More than 3000 species 


\section{直接copy本文内容时会有误差, 请注意核对!}

were sent to us. The list is not complete and we may estimate that the figure, if complete, will be above 4000 . Of course, this figure is a roughly estimated one. It is an urgent task to make a general survey on endangered plants, to prepare an accurate list of them, to study their biological properties and to work out scientific measures to conserve them.

According to our present knowledge, a considerable number of plant species in China have been extinct. Perhaps the precise figure of them can never be known. When we made a survey on some endangered plants for preparing Vol. 1 and 2 of "China Red Data Book of Plants", several tens of species could not be found, though having been searched for years. Among them are Ormosia howii. Hopea mollissima, Nyssa yunnanensis, Carallia diplopetala, Dunnia sinensis, Mussaenda anomala, Diplandrochis sinica, Archineottia gaudissartii, etc. . They may have become extinct. Even more species have only one or a few individuals surviving, e. g. Carpinus putoensis, Ostray rehderiana, and Abies beshanzuensis in Zheijiang Province, Bhesa robusta, Apterosperma oblata. Euryodendron excelsum and Chuniophoenix hainanensis in Hainan. As roughly estimated, about $5 \%$ of the species on the list of endangered plants have disappeared during the recent several decades. Speculated in this way, at least 200 plant species have recently become extinct in China.

The statistics of communities indicates that one plant species coexists with $10 \sim 30$ species of other organisms (e. g. animals, fungi): plants provide them with food and suitable habitats. Therefore, extinction of one plant species will cause disappearance of $10 \sim 30$ species of other organisms. According to this estimate, since there are $4000 \sim 5000$ species of endangered plants, there will be 40 or 150 thousands of species of other organisms being vulnerable. Because more than 200 plant species have become extinct recently, as estimated above, it is quite possible that $2000 \sim 6000$ species of other organisms have also disappeared during this period. It would be a criminal act of human being if not to take effective measure to conserve endangered plants under this condition.

We appeal for that protection of environments and conservation of endangered organisms should become a national policy of China. 